\title{
The role of higher education in sustaining culturally significant crafts in Estonia
}

\section{Kokko, Sirpa}

$T \& T$ Clark

2018-02-08

Kokko , S 2018, The role of higher education in sustaining culturally significant crafts in Estonia . in S Walker , M Evans , T Cassidy , J Jung \& A Twigger Holroyd (eds) , Design Roots : Culturally Significant Designs, Products and Practices. T \& T Clark, London, pp. 231-242 . < http://www.bloomsbury.com/uk/design-roots-9781474241816/ >

http://hdl.handle.net/10138/235315

draft

Downloaded from Helda, University of Helsinki institutional repository.

This is an electronic reprint of the original article.

This reprint may differ from the original in pagination and typographic detail.

Please cite the original version. 


\title{
17
}

\section{The Role of Higher Education in Sustaining Culturally Significant Crafts in Estonia}

\author{
Sirpa Kokko
}

\section{Introduction}

In the present world of globalization, mass production, and consumerism, there is a danger that local craft traditions will be lost (Kokko and Kaipainen 2015). Often, the material representations of local craft traditions have been placed into museums and archives, where they represent the relics of the past. However, the counterforce of grassroots-level activism is keeping these traditions alive in various parts of the world (Hackney 2013). Crafts connect people across national boundaries in new ways, utilizing new forms of web-based media (Gauntlett 2011).

In Estonia, crafts still play an important role in local culture, with an abundance of craft galleries, workshops, and markets. There is also a wide range in terms of quality: from high-quality art and design crafts to quickly made hobby crafts. Although Estonian knitting and textiles are the most well known (e.g. Kabur, Pink, and Meriste 2011), others such as jewellery, bone-craft, wood, metal, and ceramics can also be found. During the recent Soviet rule (until 1991), there was a shortage of goods in the shops and Estonians needed to be capable of producing many things for their daily use themselves. Consequently, a living tradition of handmaking in Estonia continues today, and hobby crafts are widely practiced (Annist 2009; Parts 2015).

In many countries, craft has been removed from comprehensive school education but in Scandinavian and Baltic countries, craft has the status of a standard school subject (Kokko 2009; Müürsepp 2014). The focus of higher education on art, craft, 
and design is facing constant changes, as seen in the UK (Journeaux, Wade, and Bolton 2015). In the higher education institutions, cultural and traditional aspects may be included in their arts, crafts, and design curricula, (e.g. University of Leeds in the UK), but often the focus is on design, digitalization, and an industrial approach (e.g. Aalto University in Finland). In Estonia, Viljandi Culture Academy (VCA), ${ }^{1}$ one of the four colleges of the University of Tartu, aims to sustain and develop the values of Estonian traditional culture. It offers graduate and undergraduate study programmes in such fields as theatre and dance arts, Estonian native crafts, music, sound engineering, leisure studies and culture management. The Department of Estonian Native Crafts also provides higher education in the fields of Estonian native textiles, construction and metalwork. The website of the Department (UT, VCA 2016) explains that "The mission of the department is to represent the local and native traditions and values that strengthen the sense of identity. This is done by integrating traditional craft techniques into contemporary functional milieu." The institution claims to be unique in the world in concentrating on Estonian crafts.

The purpose of the case study presented in this article was to find out how the Department of Estonian Native Crafts is sustaining Estonian craft traditions. The analysis focuses on the role of higher education in sustaining culturally significant crafts.

\section{Methods}

According to Verschuren (2003: 121), "the object of a case study is one single case, temporally, physically or socially limited in size, complex in nature, unique and thus not comparable with other cases." This description applies very well to VCA, the object of this case study. As is typical of a case study, the research utilized a variety of qualitative data-collecting procedures (ibid.: 125). Participatory observation (e.g. Marvasti 2014) was used during the four visits to VCA, one week at a time: twice in 2012, and once in 2014 and 2015 respectively. The visits were part of a teacher and researcher exchange programme, and included participation in activities at VCA. Craft exhibitions and museums were also explored widely; observations were documented via notes and photos.

To get an in-depth view, the department curriculum developer, three teachers and four former students were individually interviewed in 2014. The interviews were semi-structured, meaning that a list of questions was followed, although not rigidly (e.g. Kvale 1996). The interview questions concerned the background of the informants, how they had learned their craft, and how they made a living through craft. The role of VCA in their professional development was discussed. Further questions concerned their perceptions of the future of craft.

The interviewees were chosen to represent different aspects and study fields of VCA, and will be introduced later in the article. The interviews with the teachers were conducted in English; one of the teachers helped with the English translations of three of the student interviews.

The analysis here relies mainly on the interviews but is supported by the notes taken during participatory observation. The transcribed interviews were analyzed 
according to the basic ideas of qualitative data analysis (Flick 2014). Each interview was listened to several times to get an overall understanding. After that, the transcriptions were coded and clustered thematically according to the discussions related to the experiences of teaching and studying in VCA. This analysis forms the basis for exploring the role of VCA in sustaining culturally significant crafts.

\section{Teaching and studying in VCA}

The study programme of VCA consists of theoretical and practical craft studies. In their theses, both the BA and MA students concentrate on a chosen field of Estonian craft tradition and study its background, materials and technical variations. They search for the roots of their chosen Estonian craft in museums and archives. In addition, they conduct fieldwork to learn about the living practices that are still available. Based on these findings, they create designs, products, and practices that offer a better fit for present-day purposes.

The institution collects these BA and MA theses in online archives (Rahvuslik Käsitöö 2016) and some of the students present their findings in the VCA's publication, Studia Vernacula (2014). However, since the work is mainly in Estonian, it is not easily accessible to an international audience. In addition to their basic educational programmes, VCA also educates the wider community in craft traditions and entrepreneurship (Summatavet 2012).

The informants had typically tried many different career paths before starting their studies in VCA. In fact, when they made their first career choice, they had not known about the possibility of academic craft studies. All of the informants had an earlier interest in making crafts as a hobby. They had learned these skills mainly at home and from relatives or neighbours. Crafts had also been taught also at secondary school. Below, is a brief introduction of the interviewees using their full names. Later in the chapter, only their first names will be used.

\section{Teachers}

Anu Raud, a famous tapestry artist, was the person who first developed the craft curriculum for the department (see Reinholm 2013); she was interviewed to find out about the background of the department. She had studied textile arts at the Estonian State Art Institute. Before starting to work at VCA, she had a career as a designer at Folk Art Company "UKU" and as a lecturer at the Estonian Academy of Arts. She came to live in her family's country house near Viljandi in 1990 and became involved with VCA. She initiated a new curriculum, then called Farm Design and Handicrafts. She also started to restore the Heimtali Museum and donated her vast collection of folk art (see Reinholm 2013). Since then, the museum has been used as part of the studies in VCA. Anu utilizes Estonian nature and traditions as a source of inspiration in her tapestries (see Figure 17.1).

Ave Matsin teaches in the Department of Estonian Native Crafts. When Ave had almost completed her MA in the Estonian Academy of Arts, she was asked to come to work at VCA, where she soon became Head of Department. She concentrates 


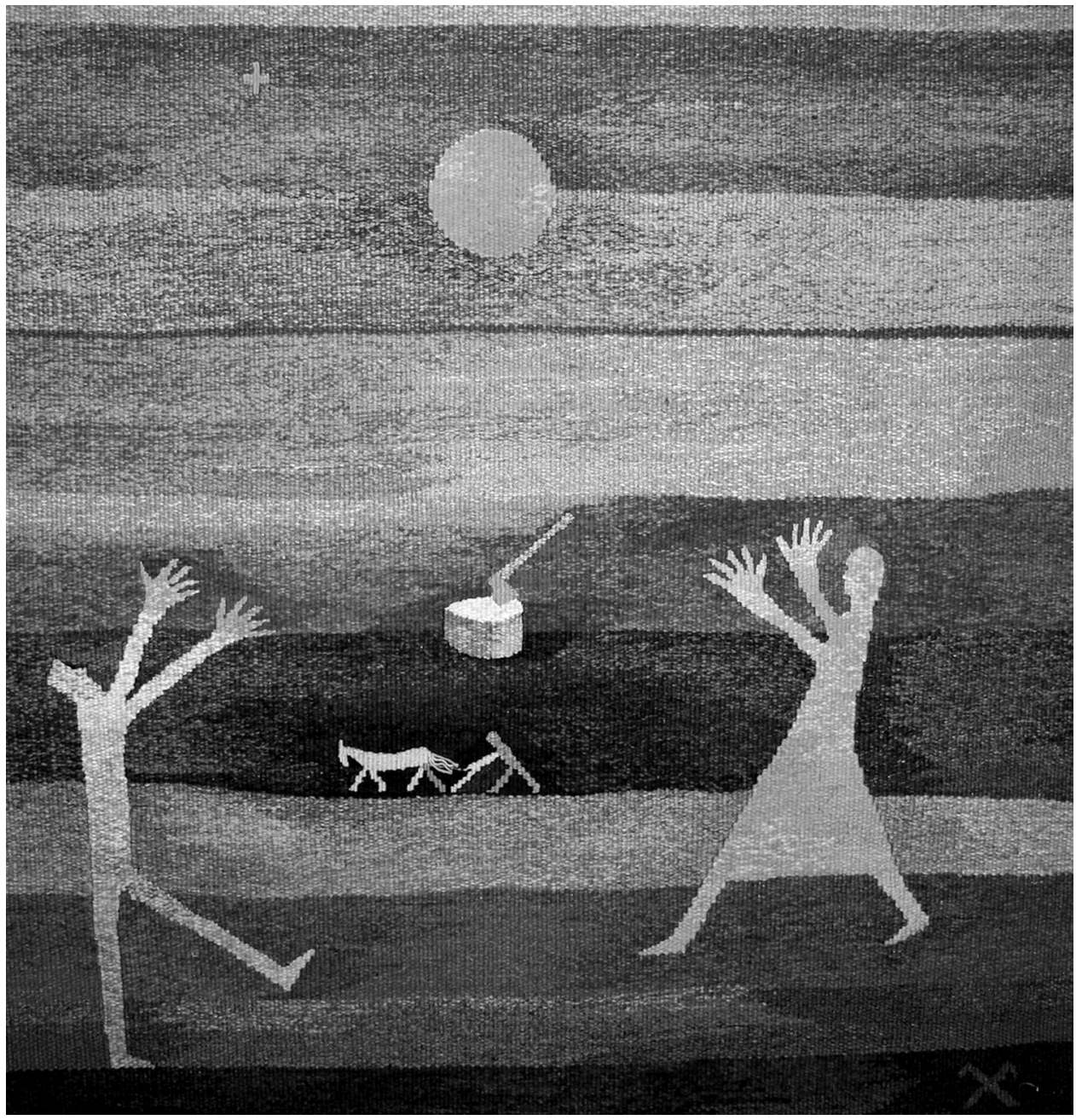

FIGURE 17.1 Example of Anu Raud's tapestry. Courtesy Kokko. (C) Anu Raud.

mainly on administration but also teaches weaving, historical textiles, and the reconstruction of old crafts as well as giving seminars on craft research. Currently, Ave is working on a $\mathrm{PhD}$ on archaeological textiles.

Kristi Jõeste is a teacher and programme manager at VCA. She gained her first academic degree at VCA and then obtained her MA degree in Semiotics at the University of Tartu (Jõeste 2012). She teaches traditional crafts, knitting, patchwork and Tunisian crochet, and gives craft research seminars with Ave. Kristi has written books on Estonian knitting (Jõeste and Ehin 2012; Pink, Reimann, and Jõeste 2016). She is a well-known knitting master herself and has had several exhibitions in Estonia and internationally (see Figure 17.2). With the help of an award from the Estonian cultural endowment, she started her own company and sells knitted gloves, mainly to order. She also employs knitters who make the gloves she designs. 


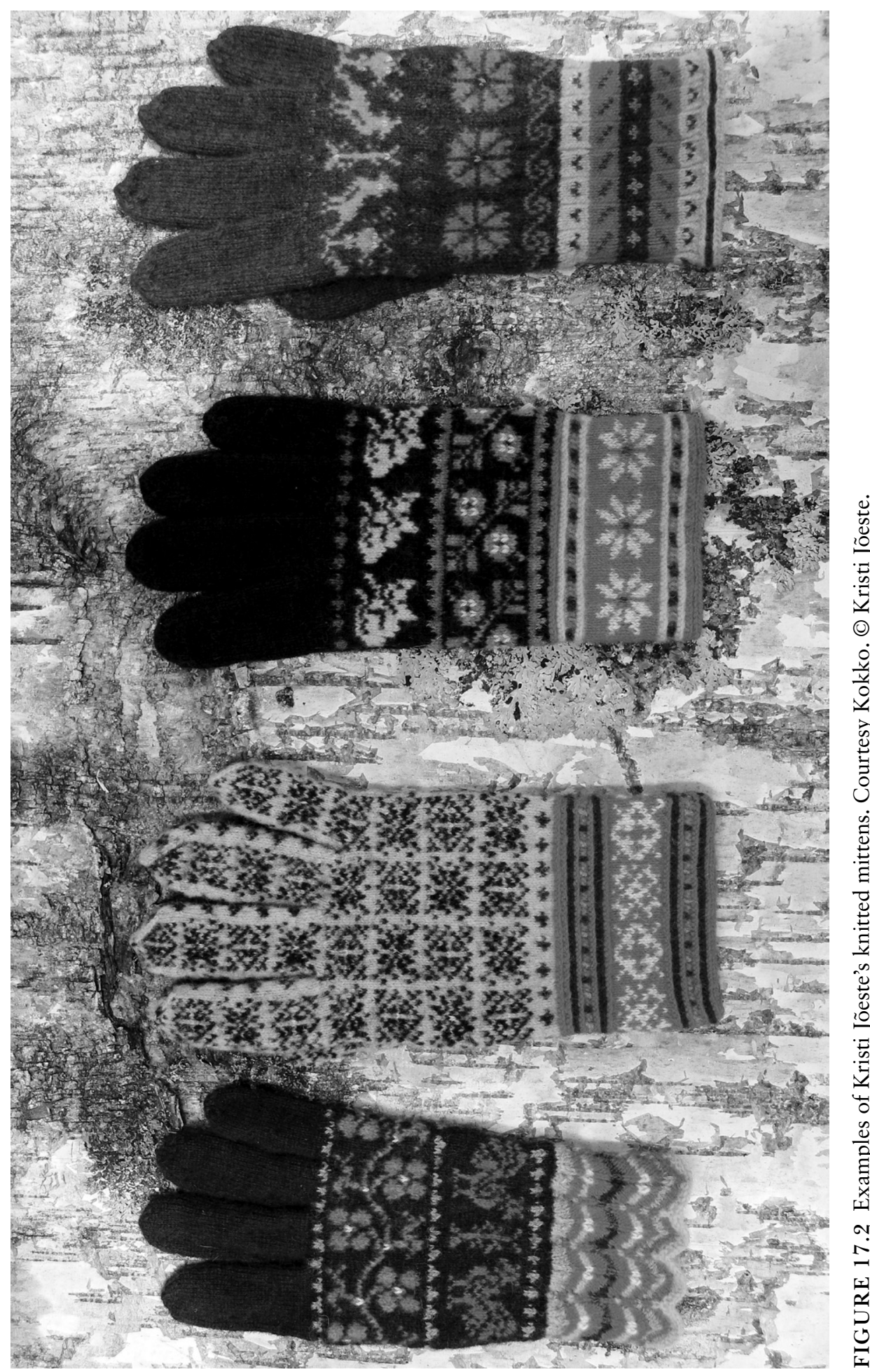


Priit-Kalev Parts is a programme manager of the Estonian native construction curriculum and a lecturer in Estonian native construction. His background is in Estonian philology and languages, and more recently in landscape architecture. He wants his students to "dream realistically." He felt students were motivated to study crafts but not to stay in the field, and has recently added more commercial aspects to the curriculum. He has just finished a PhD on community development and management (Parts 2015).

\section{Students}

Veinika Västrik first studied history at the undergraduate level at the University of Tallinn, and learned weaving in a guild and through a number of courses. Because of the flexible study arrangements, studying in VCA gave Veinika the possibility to combine MA studies with her work as a weaving teacher and her family life in Tartu. She concentrated on rep mats in her MA thesis (Västrik 2014). This is a special type of warp-faced weave where the warp threads are put so close together that no weft is visible. As Västrik (2014) notes, the making of rep weave floor coverings had been widely practiced in northern Estonia between 1950 and 1970, but was later almost forgotten. Although she already worked as a teacher of weaving, she did not have any official qualification in crafts; studying at VCA gave her the possibility to achieve one.

Andres Rattasepp had previously obtained a BA in art and craft pedagogy at the University of Tallinn, and had worked as a woodwork teacher. He entered the MA programme at VCA to learn more about the birch bark crafts that he had practiced. Birch bark crafts have long been an important part of traditional Estonian crafts but nowadays there is a danger of the skills being lost. During his studies, he found a master in Novgorod who taught him more about birch bark crafts, which helped in writing his thesis on the topic (Rattasepp 2014). Andres described the atmosphere of VCA as supportive and said that it was important for him to study there.

Kristina Libe first planned to study history, but changed her mind after hearing about the possibility to apply to VCA. She explained that she did not know exactly what she was going to study when she started her BA studies in textiles, but during the course she became interested in traditional crafts and ultimately based her diploma on traditional coats. Afterwards, she went to a vocational school to improve her skills in dressmaking.

Monika Hint was a self-employed farmer and artist before starting her BA and later MA studies at VCA. While she had always enjoyed practicing different forms of crafts, it was only at VCA that she had the opportunity to concentrate on bone crafts, which became her specialization. She explored archaeological findings in Estonia to reconstruct her own bone craft techniques, utilizing bones of agricultural animal by-products as her raw material (Hint 2013). For her, the positive learning community at VCA was important.

\section{Living and making a living with crafts}

After graduating from VCA, the former students had multiple sources of income. They all emphasized that they had gained a great deal from studying at VCA; they 
gained practical craftmaking skills, entrepreneurial skills, professional networks, self-confidence and research skills. These students were characterized by their enthusiasm about their work. They had visions about the future and were not afraid of risk-taking. The question of making a living with crafts is a central topic for all practitioners, but within the market of a small country such as Estonia it is especially demanding.

When talking about the effect of studying at VCA, Veinika thought that her work as a weaving teacher had not changed considerably. However, she was now also teaching a special field of weaving, rep mat. Together with her brother's wife, Veinika has her own company selling equipment, raw material, and books about weaving. As part of running her company, she gives courses on weaving and helps weavers to put the warp into their looms. She also weaves rep mats herself, taking inspiration from old patterns and developing them into more up-to-date designs. She sells her products in fairs and to order.

Veinika appreciated the research skills she had learned during her studies in VCA. She was planning to make handbooks for weavers, having noticed they were needed in Estonia (Freienthal and Västrik 2012). She also felt that more people were starting to weave and do handicrafts, and she thought it was because cheap Chinese products did not satisfy everyone. Instead, many people wanted to make something with their own hands and needed guidance in doing so.

At the time of the interview, Andres was working as a craft teacher in a primary school. Together with his wife, he had continued to study crafts, this time through woodwork courses, and had also been teaching on various craft courses in Olustvere. When possible, he taught his special field of crafts, birch bark work, and made birch bark artifacts for sale, but only to order. Andres had many plans for the future, and was aiming to continue doing research on birch bark crafts. At the completion of this article (2016), he had secured a position as head of a museum in Estonia.

Monica had run her own business as a bone artist for one year prior to the interview. However, during this time she had gained experience and self-confidence. She said that she could make a living together with the income of the farm she was running with her husband. During her studies at VCA, she had learned the commercial aspects of business work. She was selling her products mainly in Estonia by taking orders at markets and in the studios of other craftspeople (see Figure 17.3). She had realized that people either like or dislike her products and the idea of making something out of bones. She had also invested in a watermill to help in her work. Monica was planning to open an online shop and attend fairs. She aimed to put greater effort into advertising her work and was considering hiring someone to help with the marketing.

After finishing her studies in VCA, Kristina travelled for about a year. After returning to Viljandi, she opened her own tailoring studio within a business incubator. She also taught some courses on sewing at VCA. After the incubator period finished, she worked with two VCA graduates until they left on maternity leave. She made dresses to order and enjoyed the process of designing with the customers. Kristina intended to continue with her tailoring studio in Viljandi and was hoping to find partners to help run it. She did not want to make the business too big since she appreciated the calm lifestyle and having direct contact with her customers. She thought that the roots of crafts in Estonia were so deep that they would not die. 


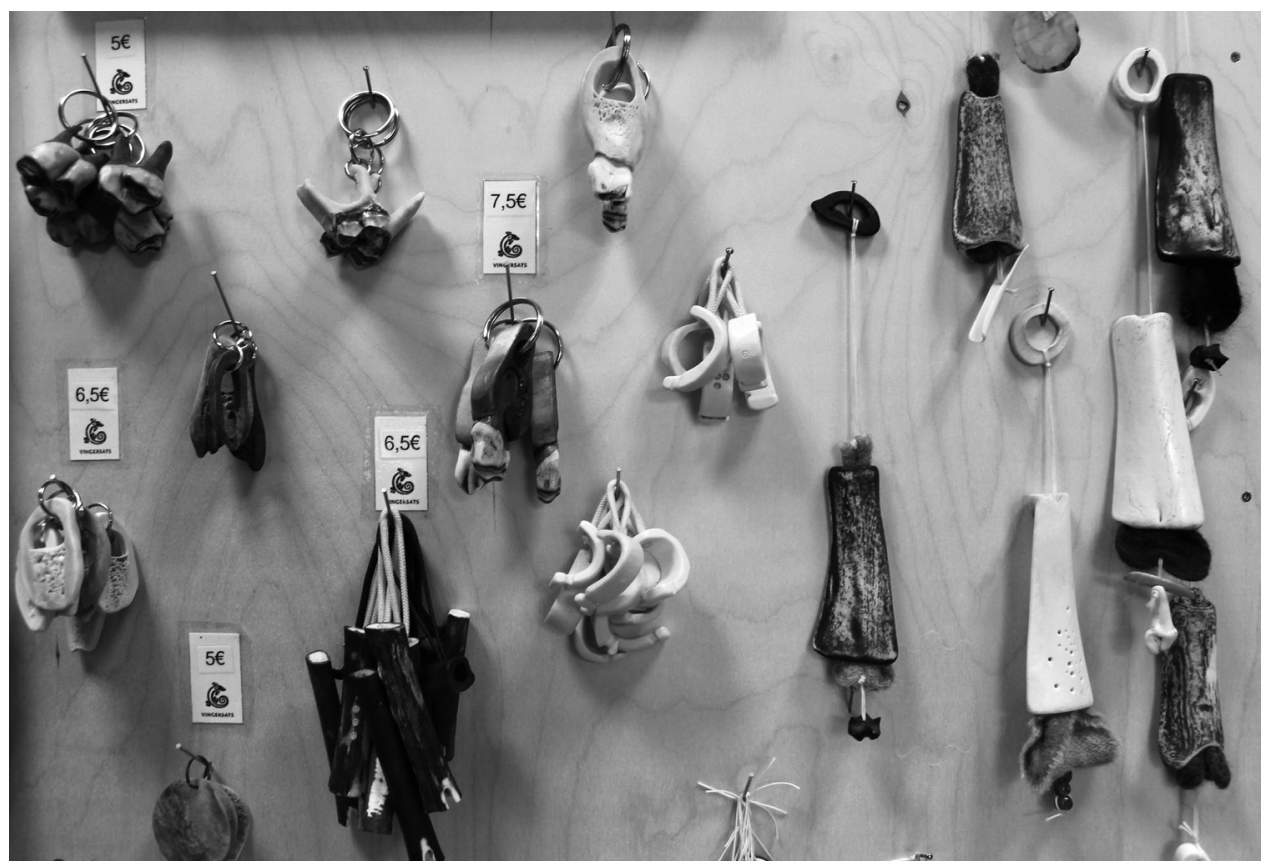

FIGURE 17.3 Examples of Monika Hint's bone crafts. Courtesy Kokko. @ Monika Hint.

The interviewees shared the idea that crafts still play an important role in Estonian society, where there are many skilful craftspeople and hobbyists. Kristina pointed out that craftmaking skills may also be an obstacle for selling craft products; often people are not ready to buy something if they think that they would be capable of making it themselves. Yet Kristina could see a difference between the professional and a hobby craftsperson in terms of design and taste. Even though hobby craftmakers may reach a good level of technical quality, compared to educated professionals there is a difference in the quality of design. She remarked on the competition at markets between professional and hobby craftspeople; the latter often sell their products at a much cheaper price. Kristina stressed the importance of recognizing the variety and value of one's own traditional crafts.

\section{Future of crafts in Estonia and VCA}

During the discussions about the future of crafts, Ave thought that because making by hand is not a necessity anymore, people will lose their skills over time. She was worried about crafts being mainly connected to hobbies, rather than professional or artistic dimensions. In her mind, the mission and role of VCA is to highlight the richness of Estonian craft traditions and also help people to realize that craftmaking can be a profession. Ave thought that it was important to introduce the students to the vast variety of professional opportunities relating to crafts. She highlighted the 
importance of people who are role models, such as the Estonian, Reet Aus (2011), who uses waste textiles to create new work. Also, she noted the need to further develop existing craft research.

Kristi was very concerned about the fact that there are few living craft masters from whom people could learn craft traditions. She mentioned Kihnu Island as the best place for knitting traditions to thrive (Jõeste 2012; Summatavet 2010). She has explored the varieties of knitting traditions all around Estonia and utilized them in her contemporary knitting (Jõeste and Ehin 2012). Kristi thought that Estonian knitting has international importance due to its uniqueness and variety of techniques. She argued that it is important to be aware of these specialities, and to preserve them. She considered herself and others to be the "missionaries of knitting." Kristi is fulfilling this role with great success: her knitting courses are always full. Women of different ages attend her courses: older ones to get some help in making the complicated traditional patterns, the younger ones to learn techniques they have not learned anywhere else. She felt that crafts are important for the Estonian national identity, but fears there is a danger of craft skills disappearing over time. However, she believed that there are also counterforces to the globalizing tendencies and there will always be people who value handmade crafts. She had noticed that more small-scale craft entrepreneurs were starting up in Estonia, which she thought to be a sign of people choosing a certain lifestyle.

Kristi was happy that VCA has decided to establish research in craft, as this has helped them to develop their teaching and research work. For her, the mission of VCA was important in preserving and developing traditional Estonian crafts as part of the Estonian national identity. She raised the topic of education in cultural heritage and crafts (see Kokko and Dillon 2016) and would like to add aspects of Estonian traditional craft culture into the craft education of secondary schools.

When thinking about the possibilities to earn a living by making crafts, Priit-Kalev concluded that some possibilities exist, "if the craft person's demands are not high and he can build up a personal relationship with clients. This is what the clients miss: the clients want the story." According to him, Estonians appreciate their heritage and have a romantic view of the past. Priit-Kalev was interested in developing the aspect of spirituality in craft culture and researching the inner motivation of making crafts. He was talking about the interaction of cultures which would, on one hand, lead to global identities, and on the other, strengthen local identities as an opposing force.

Anu had noticed the abundance of quickly handmade crafts of poor quality being sold at local markets to tourists at a lower price than the high-quality crafts. For Anu, being over seventy years old, her main worry was to take care that her work would be continued. She did not approve of the globalizing effects and mixing of cultures. She was happy about the current state of things in VCA, but spoke about the importance of keeping a balance between theoretical and practical studies.

\section{Discussion and conclusions}

There is a growing interest in crafts and handmaking skills, which has arisen recently in academic research (Greenhalgh 2002; Charny 2011; Sennett 2008). The importance of education at all levels in recognizing the value of craft as both 
skilled and intellectual activity, and its relevance for cultural understanding, is also discussed more widely (Kokko and Dillon 2016; Niedderer and Townsend 2013). Drawing on the analysis of this study, VCA has an important role in sustaining culturally significant craft designs, products and practices in Estonia, in carrying out research and in showing their importance to a wider society. For an institution of higher education, VCA is unique in the world with its mission of making Estonian crafts and their designs visible, and in developing them to adapt to present-day purposes. Evidently, opportunities should be given to similar institutions in other countries to sustain their cultural traditions. The work of the School of Design at the University of Leeds is a good example of similar approaches but with a wider global perspective and more extensive use of ICT (Shin, Cassidy, and Moore 2015). Since the Estonian language is only spoken within the population of 1.3 million Estonians, there is a need for efforts to reach a wider audience. In fact, VCA is making plans to open up an international study programme on crafts and related fields. Furthermore, they have plans to place greater emphasis on international cooperation and research.

The history of Estonia has had an impact on the continuance of local craft traditions. Compared to many other countries, Estonia is still culturally homogenous; this makes it easy to explore native craft traditions. For a small country that has gained independence relatively recently, to survive as a nation it is important to preserve various forms of tradition, including crafts. Annist (2009) notes that the Estonian cultural sphere was already highly formalized in the nineteenth century and that Soviet cultural hegemony was never properly established; instead it enabled the perseverance of nationalist cultural counter-hegemony. "Especially in the later years of the Soviet rule, there were hobby-groups that appeared apolitical but would spread nationalist mentality" (Annist 2009: 119). Accordingly, the Estonians actually never lost their cultural heritage and identity under the occupation and thus, after their second independence from the Soviet Union in 1991, they had good foundations on which to construct their nation and revive their traditions.

Crafts and their studies play an important role in the interaction of global and local cultures and identity construction. In the present global society of ever-growing consumption, it is necessary to pay serious attention to sustainable design (Walker and Giard 2013). The economic sustainability of practising crafts is a topic that concerns craft professionals all around the world. Education on entrepreneurship skills is important for all higher education on art, craft and design (Hjelde 2015); this topic has demanded growing attention in the study programmes of VCA. Apparently, a successful craft entrepreneurship requires enthusiasm and risk-taking from the practitioners: the qualities possessed by the informants of this study. They have found a way of surviving by using multiple means of earning a living. For them, craft making was a choice of lifestyle that allowed them to work on the things that gave them pleasure and inner satisfaction; this outweighed the low income that was provided (see also Parts et al. 2011). The follow-up of the students' careers after they had left VCA is encouraging in showing that most of them have found or created a working place in their craft or a related field.

For the informants of this study, crafts held very important personal meanings. They talked about the inner need for making crafts, which gave them pleasure and satisfaction. Crafts provided them a means for expressing creativity and the possibility to relax. The aspect of crafts as an important part of the wellbeing of 
people is becoming more topical, not only in Western countries. Looking at the Indian context, Kasturi (2005: 75-77) notes that thinking of design only as a contributor to the economics of crafts offers design a rather limited role. Instead, its relevance to overall wellbeing and its role as an integrator between customers and craftspeople needs attention; this issue was raised by the informants of this study. When thinking about the sustainable future of crafts, these aspects require attention in the study programmes of crafts and design in higher education.

\section{Note}

1 The Academy has offered specialized culture education since 1952. The former Viljandi Culture School was recognized as a college providing applied higher education in 1991, and it joined the University of Tartu in 2005. MA level studies were introduced in 2011 (UT, VCA 2016).

\section{References}

Annist, A. (2009), “Outsourcing Culture: Establishing Heritage Hegemony by Funding Cultural Life in South Eastern Estonia," Lietuvos Etnologija: socialinés antropologijos ir etnologijos studijos, 9 (18): 117-138.

Aus, R. (2011), Trash to Trend-Using Upcycling in Fashion Design, Tallinn: Estonian Academy of Arts.

Charny, D. (ed.) (2011), Power of Making: The Importance of Being Skilled, London: V \& A Publishing and the Crafts Council.

Flick, U. (ed.) (2014), The SAGE Handbook of Qualitative Data Analysis, London: SAGE.

Freienthal, M. and Västrik, V. (2012), Lapilised Vööd (Lapilised Belts), Tallinn: Saara Kirjastus.

Gauntlett, D. (2011), Making is Connecting: The Social Meaning of Creativity, from DIY and Knitting to YouTube and Web 2.0, Cambridge: Polity Press. Available online: http:// www.makingisconnecting.org (accessed June 1, 2016).

Greenhalgh, P. (ed.) (2002), The Persistence of Craft, London: A\&C Black.

Hackney, F. (2013), "Quiet Activism and the New Amateur: The Power of Home and Hobby Crafts," Design and Culture, 5 (2): 169-193.

Hint, M. (2013), "Luu töötlemine lamba sääreluust vilepilli näitel,”Lugusid materjalidest. Stories about materials. Studia Vernacula, 3: 58-72.

Hjelde, K. (2015), "Paradox and Potential: Fine Art Employability and Enterprise Perspectives," Art, Design \& Communication in Higher Education, 14 (2): 175-188.

Jõeste, K. (2012), Kihnu kördid eile ja tänä. (Book about Folk Skirts of Kihnu Island) Semiootiline esemeuurimus, Studia Vernacula, Viljandi: Eesti Loomeagentuur.

Jõeste, K. and Ehin, K. (2012), Ornamented Journey, Turi: Saara Publishing House.

Journeaux, J., Wade, S., and Bolton, T. (2015), “Controversy and Conformity—25 Years of Transforming the Academy," Art, Design \& Communication in Higher Education, 14 (2): 107-110.

Kabur, A., Pink, A., and Meriste, M. (2011), Designs and Patterns from Mubu Island. A Needlework Tradition from Estonia, Estonia: Saara Publishers.

Kasturi, P. B. (2005), “Designing Freedom,” Design Issues, 21 (4): 68-77. 
Kokko, S. (2009), "Learning Practices of Femininity through Gendered Craft Education in Finland," Gender and Education, 6 (21): 721-734.

Kokko, S. and Dillon, P. (2016), "Engaging Trainee Teachers with Crafts and Cultural Heritage," International Journal of Education through Art, 12 (1): 21-37.

Kokko, S. and Kaipainen, M. (2015), “The Changing Role of Cultural Heritage in Traditional Textile Crafts from Cyprus," Craft Research, 6 (1): 9-31.

Kvale, S. (1996), InterViews: An Introduction to Qualitative Research Interviewing, Thousand Oaks, CA: SAGE.

Marvasti, A. B. (2014), "Analysing Observations," in U. Flick (ed.), The SAGE Handbook of Qualitative Data Analysis, 354-366, London: SAGE.

Müürsepp, M. (2014), “Cooking and Hammering: Primary School Pupils' Concepts of Their Craft Skills," International Electronic Journal of Elementary Education, 6 (3): 371-384.

Niedderer, K. and Townsend, K. (2013), “Craft, Society and the State," Craft Research, 4 (2): 153-159.

Parts, P.-K. (2015), Sustainable Community Management in Estonia: Reflections on Heritage Projects on Kihnu Island, in Viljandi County, and in Various Protected Areas, Tartu: Eesti Maaülikool/Estonian University of Life Sciences.

Parts, P.-K., Rennu, M., Jääts, L., Matsin, A., and Metslang, J. (2011), “Developing Sustainable Heritage-Based Livelihoods: an Initial Study of Artisans and Their Crafts in Viljandi County, Estonia," International Journal of Heritage Studies, 17 (5): 401-425.

Pink, A., Reimann, S., and Jõeste, K. (2016), Estonian Knitting: Customs and Techniques, Vol 1, Türi: Saara Publishing House.

Rahvuslik käsitöö (2016), The Online Archive of Thesis of the Department of Native Crafts, VCA. Available online: http://kultuur.edu.ee/rahvuslik/?dir= (accessed June 1, 2016).

Rattasepp, A. (2014), "Kasetohust punutud Eesti ala märsid: eripärad ja valmistamine," (Estonian Birch Bark Pouches: Particularities and Weaving Techniques), Käegakatsutav. The Tangible. Studia Vernacula, 5: 69-93.

Reinholm, V. (2013), Anu Raud. Estonian Textile Artist, Tallinn: Valgus.

Sennett, R. (2008), The Craftsman, London: Penguin Books.

Shin, M. J., Cassidy, T., and Moore, E. M. (2015), "Design Reinvention for Culturally Influenced Textile Products: Focused on Traditional Korean Bojagi Textiles,” Fashion Practice, 7 (2): 175-198.

Studia Vernacula (2014), 5, Käegakatsutav. The tangible. University of Tartu Viljandi Culture Academy.

Summatavet, K. (2010), My History. The letters of Kibnu Roosi, Viljandi: Viljandi Culture Academy and Varrak Publishers.

Summatavet, K. (2012), Käsitöögä tööle 2. Handicraft for Job 2, University of Tartu Viljandi Culture Academy.

UT, VCA (2016), University of Tartu Viljandi Culture Academy. Available online: http:// www.kultuur.ut.ee/en/departments/crafts (accessed June 1, 2016).

Verschuren, P. J. M. (2003), "Case Study as a Research Strategy: Some Ambiguities and Opportunities," International Journal of Social Research Methodology, 6 (2): 121-139.

Västrik, V. (2014), "Lõimeripstehnikas põrandakatete kuduminen Avinurmes 1950-1970 aastatel kui piirkondlik pärandoskus" (Production of Rep Weave Floor Coverings in Avinurme in the 1950s to the 1970s as a Regional Inherited Skill), Käegakatsutav. The Tangible. Studia Vernacula, 5: 47-68.

Walker, S. and J. Giard (eds) (2013), The Handbook of Design for Sustainability, London: Bloomsbury. 